\title{
Biophysical qualities of the hoof horn and its influence on cows productive longevity
}

\author{
Sergey Karamaev ${ }^{1, *}$, Nina Cumshewa ${ }^{2}$, Khaidar Valitov ${ }^{1}$ and Anna Karamaeva ${ }^{1}$ \\ ${ }^{1}$ Samara State Agrarian University, 2, st. Educational, 446442, Kinel, Russia \\ ${ }^{2}$ Penza State Agrarian University, 30, st. Botanical, 440014, Penza, Russia
}

\begin{abstract}
The main research objective was to study the influence of the hoof shape, hardness and elasticity of the hoofed horn on the cows' productive use period duration in modern dairy complexes. The research object was black-motley cows, rejected due to limb disease. The shape of the hoof is divided into normal, with angle of $45-55^{\circ}$, sharp - less than $45^{\circ}$ and obtuse - more than $55^{\circ}$. In the group of retired cows with the correct shape, there was $76 \%$ of animals. Studies have shown that $55.2 \%$ of cows had a hoof hardness 80-85 ShA, but the longest period of life was in animals with a score of 91 or more ShA, and the maximum lifetime milk yield - with an indicator 86-90 ShA. Most of $(61,6 \%)$ retired cows had an indicator of hoof horn elasticity $3,1-3,5 \times 10^{10} \mathrm{~Pa}$. Moreover, the highest rates of productive longevity were observed in cows with hoof horn elasticity $2,6-3,0 \times 10^{10} \mathrm{~Pa}$. Therefore, for further use, it is desirable to select animals having front wall inclination angle of the hoof $50-55^{\circ}$, with hardness hoofed horn $86-90$ ShA, and elasticity $2,6-3,0 \times 10^{10} \mathrm{~Pa}$.
\end{abstract}

\section{Introduction}

The modern milk production technology, based on the intensification of all production processes, assuming its maximum mechanization and automation, creates very stringent conditions for keeping and operating animals. Large-group loose housing on concrete floors, year-round uniform feeding on the background of inactivity, the mismatch of technology elements to the physiological needs and a number of other reasons led to a noticeable increase in diseases of cattle stock limbs, especially in dairy cows [1-4].

The introduction of highly mechanized industrial technologies into dairy cattle breeding, in the presence of various constructional drawbacks in the design and construction of cattle breeding complexes, significantly increases injuries, leads to stressful situations and general discomfort. All this ultimately leads to a decrease in the natural organism resistance and negatively affects the productive longevity of animals. Zero grazing of cows at the milk production complexes due to the lack of exercise leads to impaired blood and lymph circulation in fingers, which is accompanied by development of hyperkeratosis, deformation of hooves, impaired limbs staging, pathology of tendonligamentous apparatus and joints [5-8].

\footnotetext{
*Corresponding author: KaramaevSV@mail.ru
} 
Diseases of legs and lameness in cows are found in all types of dairy complexes and make up about $30-35 \%$ of the total number of diseases in cattle stock. European scientists note that the problem of hoof disease is of economic importance, since its solution is spent annually from 1750 to 3724 dollars for a herd of 100 cows. According to G. Gramera (2008), in Europe, the prevalence of leg damage is approximately $50 \%$ in stall systems and $70-80 \%$ in loose keeping [9-12].

Many researchers indicate that the horn capsule, its shape and biophysical qualities play a decisive role in protecting the soft tissue of the hoof and the pathogenesis of its diseases. Most of them claim that the shape of the hooves and the quality of the hoofed horn are highly inherited traits, which makes it possible to breed animals with a strong hoofed horn. For this, it is necessary, as part of the breeding work with the herd, to conduct an all-round assessment of the horn shoe shape and the animal hoof biophysical properties, including these characteristics in selection plan. The main criteria for assessing the hoof shoe quality can be considered hardness, elasticity, length, width, height and front wall inclination angle. Moreover, in order to correctly evaluate the function and properties of the hoofed horn, it is necessary to study and understand its structure, to know how the horn is formed during keratinization, what factors have a fundamental influence on its biophysical qualities and properties [13-15].

Since, ultimately, the quality and health of cattle stock is of economic importance, the goal of our research was to study the effect of hoof shape, hardness and elasticity of the hoofed horn on the cows' productive use period duration in modern dairy complexes.

\section{Material and methods}

The studies were carried out in a modern dairy complex CJSC "Konstantinovo" in Penza region. The object of research was black-motley cows. To study the main factors affecting productive longevity, an electronic database was created that includes information on 250 cows that were retired in 2016-2018 due to limb disease. Cows with incomplete or inferior lactation (less than 240 days) and unreliable origin were excluded from statistical processing. The obtained data was systematized in the form of information mockups for each factor, followed by processing of digital material using the Microsoft Excel analysis package.

In accordance with the general research scheme, cows were evaluated: milk yield for the first, highest and average for lactation, life-time milk yield, life expectancy and productive use, and milk yield per day of life and lactation.

CJSC "Konstantinovo" is the originator in the development of a new Middle Volga type of black-motley breed, therefore, along with generally accepted breeding indicators in animals, limbs setting, hooves horn shoe shape, hardness and elasticity of hoof horn were evaluated. The front wall inclination angle of hoof horn was evaluated by a tool developed by Khaidar Valitov and Sergey Karamaev. The hoofed horn hardness was determined by the Shore method, and the elasticity (Young's modulus) was determined by the method of R. Hook and T. Jung.

To study the trait influence degree on cows productive longevity indicators, all the livestock analyzed according to the results of studying the front wall inclination angle of hoof horn was divided into 4 groups with an interval of 5 degrees, studying the hoof hardness with an interval of 5 Shore hardness units (ShA), elasticity - at intervals $0,3 \times 10^{10}$ $\mathrm{Pa}$. 


\section{Research results}

The analysis of economic use results of the black-motley breed cows, which have left the herd due to various diseases of limbs, showed that the morphological and biophysical characteristics of the horn shoe of animal hooves are the cause of the disease. Studies have shown that the shape of the hooves has a significant effect on the health of the limbs, and ultimately on the productive qualities and cows' productive use period duration (table 1).

Table 1. Productive longevity of cows, depending on front wall inclination angle of hoof horn with respect to the plantar surface.

\begin{tabular}{|l|c|c|c|c|}
\hline \multirow{2}{*}{\multicolumn{1}{|c|}{ Indicator }} & \multicolumn{4}{|c|}{ Hoof angle of with plantar surface. degrees } \\
\cline { 2 - 5 } & $\begin{array}{c}\text { I group } \\
\mathbf{4 5} \text { and less }\end{array}$ & $\begin{array}{c}\text { II group } \\
\mathbf{4 6 - 5 0}\end{array}$ & $\begin{array}{c}\text { III group } \\
\mathbf{5 1 - 5 5}\end{array}$ & $\begin{array}{c}\text { IV group } \\
\mathbf{5 6} \text { and more }\end{array}$ \\
\hline Livestock of cows: units/\% & $50 / 20.0$ & $68 / 27.2$ & $122 / 48.8$ & $10 / 4.0$ \\
\hline Live duration. days & $* * * 1469 \pm 30.6$ & $* * * 1885 \pm 28.3$ & $2164 \pm 24.9$ & $* * * 1863 \pm 32.4$ \\
\hline Productive use duration: days & $* * * 601 \pm 31.8$ & $* * * 957 \pm 11.4$ & $1186 \pm 10.6$ & $* * * 925 \pm 14.2$ \\
\hline Lactations & $* * * 11.8 \pm 0.21$ & $* 2.8 \pm 0.16$ & $3.4 \pm 0.18$ & $* * 2.6 \pm 0.23$ \\
\hline Lifetime milk yield. kg & $* * * 8349 \pm 736$ & $* * 14476 \pm 872$ & $18447 \pm 948$ & $* * * 11172 \pm 657$ \\
\hline $\begin{array}{l}\text { Average milk yield for } \\
\text { lactation. kg }\end{array}$ & $* * * 4637 \pm 93$ & $* 5168 \pm 106$ & $5423 \pm 127$ & $* * * 4296 \pm 132$ \\
\hline $\begin{array}{l}\text { Highest milk yield for } \\
\text { lactation. kg }\end{array}$ & $* * * 4869 \pm 117$ & $* 5614 \pm 124$ & $5978 \pm 132$ & $* * * 4369 \pm 139$ \\
\hline Milk yield for 1 day of life. $\mathrm{kg}$ & $* * * 5.7 \pm 0.42$ & $* 7.7 \pm 0.34$ & $8.5 \pm 0.40$ & $* * * 6.0 \pm 0.33$ \\
\hline $\begin{array}{l}\text { Milk yield for 1 day of } \\
\text { lactation. kg }\end{array}$ & $* * 13.9 \pm 0.48$ & 15.10 .43 & $15.6 \pm 0.45$ & $* * * 12.1 \pm 0.51$ \\
\hline
\end{tabular}

Note: $* * * \mathrm{P}<0,001 ; * * \mathrm{P}<0,01 ; * \mathrm{P}<0,05$.

In accordance with the front wall inclination angle of hoof horn with respect to the plantar surface, the shape of the hoof is divided into normal (regular) angle of $45-55^{\circ}$, oblique (sharp) - less than $45^{\circ}$ and steep (obtuse) - more than $55^{\circ}$.

It was found that in the group of retired cows with the correct hoof shape there was $76 \%$, with sharp $-20 \%$, with obtuse $-4 \%$ of animals. Moreover, in the subgroup with the correct shape, most of the cows $(64.2 \%)$ had an angle of $51-55^{\circ}$, or $48.8 \%$ of the total population.

The longest period of life (2164 days) was observed in cows of group III, which exceeded peers in group I by 695 days $(47,3 \%$; $<<0,001)$, group II - by 279 days $(14,8 \%$; $\mathrm{P}<0,001)$, group IV - by 301 days $(16,2 \% ; \mathrm{P}<0,001)$. According to the productive use period duration, the difference was, respectively 585 days $(97,3 \% ; \mathrm{P}<0,001), 229$ days $(23,9 \% ; \mathrm{P}<0,001), 261$ days $(28,2 \% ; \mathrm{P}<0,001)$.

On average, lactation duration period in cows in the herd varies within 320-350 days. The longest lactation period was in cows of group III (3.4 lactations), which is 1.6 lactations more than the animals of group I $(88,9 \%$; $<<0,001)$, group II - by 0,6 lactations $(21,4 \% ; \mathrm{P}<0,05)$, group IV - by 0,8 lactations $(30,8 \% ; \mathrm{P}<0,01)$.

The highest milk yield for the entire period of productive use (lifelong) was also in group III $-18447 \mathrm{~kg}$, or an average of $5423 \mathrm{~kg}$ of milk per lactation. Difference compared to group I composed $10098 \mathrm{~kg}$ of milk $(120,9 \%$; $\mathrm{P}<0,001)$, group II $-3971 \mathrm{~kg}(27,4 \%$; $\mathrm{P}<0,01)$, group IV $-7275 \mathrm{~kg}(65,1 \% ; \mathrm{P}<0,001)$.

In terms of milk yield per 1 day of life, cows of group III exceeded peers from group I by $2.8 \mathrm{~kg}(49,1 \% ; \mathrm{P}<0,001)$, group II - by $0,8 \mathrm{~kg}(10,4 \% ; \mathrm{P}<0,05)$, group IV - by $2,5 \mathrm{~kg}$ $(41,7 \%$; $\mathrm{P}<0,001)$, for milk yield per 1 day of lactation, respectively by $1,7 \mathrm{~kg} \Gamma(12,2 \%$; $\mathrm{P}<0,01), 0,5 \mathrm{~kg}(3,3 \%), 3,5 \mathrm{~kg}(28,9 \% ; \mathrm{P}<0,001)$.

Having studied the hoofed horn hardness, it was found that most of the retired cows $(5,2 \%)$ had a keratin shoe wall hardness within $80-85$ ShA (table 2). The longest period of 
life (2080 days) was in animals of group IV, which exceeded peers from group I by 761 days $(57,8 \% ; \mathrm{P}<0,001)$, from group II by 134 days $(6,9 \%$; $<<0,05)$, group III - by 36 days $(1,8 \%)$.

Table 2. Productive longevity of cows depending on hoof horn hardness.

\begin{tabular}{|l|c|c|c|c|}
\hline \multirow{2}{*}{\multicolumn{1}{|c|}{ Indicator }} & \multicolumn{4}{|c|}{ Hoofed horn hardness. ShA } \\
\cline { 2 - 5 } & $\begin{array}{c}\text { I group } \\
\text { Less than 80 }\end{array}$ & $\begin{array}{c}\text { I group } \\
\mathbf{8 0 - 8 5}\end{array}$ & $\begin{array}{c}\text { III group } \\
\mathbf{8 6 - 9 0}\end{array}$ & $\begin{array}{c}\text { IV group } \\
\mathbf{9 1} \text { and more }\end{array}$ \\
\hline Livestock of cows: units/\% & $35 / 14.0$ & $132 / 55.2$ & $59 / 23.6$ & $18 / 7.2$ \\
\hline Live duration. days & $* * * 1319 \pm 32.6$ & $* 1946 \pm 29.7$ & $2044 \pm 26.9$ & $2080 \pm 34.1$ \\
\hline Productive use duration: days & $* * * 478 \pm 15.2$ & $* * * 1008 \pm 14.3$ & $1079 \pm 12.4$ & $1109 \pm 14.8$ \\
\hline Lactations & $* * * 1.3 \pm 0.19$ & $2.9 \pm 0.15$ & $3.1 \pm 0.20$ & $3.2 \pm 0.18$ \\
\hline Lifetime milk yield. kg & $* * * 5938 \pm 694$ & $15503 \pm 831$ & $17338 \pm 911$ & $* 14978 \pm 843$ \\
\hline $\begin{array}{l}\text { Average milk yield for } \\
\text { lactation. kg }\end{array}$ & $* * * 4568 \pm 98$ & $5346 \pm 94$ & $5593 \pm 118$ & $* * * 4679 \pm 136$ \\
\hline $\begin{array}{l}\text { Highest milk yield for } \\
\text { lactation. kg }\end{array}$ & $* * * 4975 \pm 118$ & $5897 \pm 110$ & $6084 \pm 123$ & $* * * 5131 \pm 148$ \\
\hline $\begin{array}{l}\text { Milk yield for 1 day of life. } \\
\text { kg }\end{array}$ & $* * * 4.5 \pm 0.39$ & $8.0 \pm 0.34$ & $8.5 \pm 0.43$ & $* 7.2 \pm 0.48$ \\
\hline $\begin{array}{l}\text { Milk yield for 1 day of } \\
\text { lactation. kg }\end{array}$ & $* * * 12.4 \pm 0.43$ & $15.4 \pm 0.38$ & $16.1 \pm 0.47$ & $* * 13.5 \pm 0.53$ \\
\hline
\end{tabular}

Note: $* * * \mathrm{P}<0,001 ; * * \mathrm{P}<0,01 ; * \mathrm{P}<0,05$

According to the cows' productive use period duration, the difference was, respectively 631 days $(132,0 \% ; \mathrm{P}<0,001), 101$ days $(10,0 \% ; \mathrm{P}<0,001), 30$ days $(2,8 \%)$.

The value of life-long milk yield is determined by productive use period duration and level of milk productivity. Most milk $(17338 \mathrm{~kg})$ was obtained from cows of group III with hoof horn hardness within 86-90 ShA. The difference compared with animals of group I was $11400 \mathrm{~kg}$ of milk $(192,0 \% ; \mathrm{P}<0,001)$, group II $-1835 \mathrm{~kg}(11,8 \%)$, group IV - $2360 \mathrm{~kg}$ $(15,8 \% ; \mathrm{P}<0,05)$.

Efficiency of milk production characterizes milk yield per 1 day of life and 1 day of lactation of cows. Based on 1 day of life, the highest milk yield $(8.5 \mathrm{~kg}$ of milk) was noted in the group III, which exceeded peers of group I by $0.5 \mathrm{~kg}(6,3 \%)$, group IV - by $1,3 \mathrm{~kg}$ $(18,1 \% ; \mathrm{P}<0,05)$. According to the milk yield per 1 day of lactation, the difference was, respectively, $3.7 \mathrm{~kg}(29,8 \% ; \mathrm{P}<0,001), 0,7 \mathrm{~kg}(4,5 \%), 2,6 \mathrm{~kg}(19,3 \%$; $<<0,01)$.

When studying the hoofed horn specimens, it was found that the hardness and elasticity indices have a rather high negative correlation dependence, i.e. the higher the hardness index, the lower the elasticity. In the group of cows that left the herd due to limb disease, $61.6 \%$ of the animals had an elasticity index of the hoofed horn $3,1-3,5 \times 10^{10} \mathrm{~Pa}$. Moreover, in animals of group II with an indicator of elasticity of $2,6-3,0 \times 10^{10} \mathrm{~Pa}$ the highest rates of productive longevity were found (table 3 ).

Table 3. Productive longevity of cows depending on hoofed horn elasticity.

\begin{tabular}{|l|c|c|c|c|}
\hline \multirow{2}{*}{ Indicator } & \multicolumn{4}{|c|}{ Hoofed horn elasticity. $\times \mathbf{1 0}^{\mathbf{1 0}}$ Pa } \\
\cline { 2 - 5 } & $\begin{array}{c}\text { I group } \\
\text { Less than 2.6 }\end{array}$ & $\begin{array}{c}\text { II group } \\
\mathbf{2 . 6 - 3 . 0}\end{array}$ & $\begin{array}{c}\text { III group } \\
\mathbf{3 . 1 - 3 . 5}\end{array}$ & $\begin{array}{c}\text { IV group } \\
\text { More than 3.5 }\end{array}$ \\
\hline $\begin{array}{l}\text { Livestock of cows: } \\
\text { units/\% }\end{array}$ & $23 / 9.2$ & $62 / 24.8$ & $154 / 61.6$ & $11 / 4.4$ \\
\hline Live duration. days & $* * * 1612 \pm 36.4$ & $2115 \pm 31.5$ & $* 2010 \pm 29.8$ & $* * * 1421 \pm 38.7$ \\
\hline $\begin{array}{l}\text { Productive use } \\
\text { duration: days }\end{array}$ & $* * * 710 \pm 18.9$ & $1145 \pm 16.4$ & $* * 1059 \pm 13.6$ & $* * * 553 \pm 19.2$ \\
\hline Lactations & $* * * 2.1 \pm 0.24$ & $3.4 \pm 0.21$ & $* * * 3.0 \pm 0.19$ & $* * * 1.6 \pm 0.23$ \\
\hline $\begin{array}{l}\text { Lifetime milk yield. } \\
\mathrm{kg}\end{array}$ & $* * * 9409 \pm 813$ & $1920 \pm 986$ & $* 15843 \pm 1136$ & $* * * 7675 \pm 769$ \\
\hline
\end{tabular}




\begin{tabular}{|l|c|c|c|c|}
\hline $\begin{array}{l}\text { Average milk yield } \\
\text { for lactation. kg }\end{array}$ & $* * * 4479 \pm 86$ & $5623 \pm 98$ & $* 5281 \pm 114$ & $* * * 4796 \pm 118$ \\
\hline $\begin{array}{l}\text { Highest milk yield for } \\
\text { lactation. kg }\end{array}$ & $* * * 5036 \pm 97$ & $6145 \pm 123$ & $* 5818 \pm 132$ & $* * * 4911 \pm 107$ \\
\hline $\begin{array}{l}\text { Milk yield for 1 day } \\
\text { of life. kg }\end{array}$ & $* * * 5.8 \pm 0.46$ & $9.0 \pm 0.38$ & $* 7.9 \pm 0.31$ & $* * * 5.4 \pm 0.43$ \\
\hline $\begin{array}{l}\text { Milk yield for 1 day } \\
\text { of lactation. kg }\end{array}$ & $* * * 13.3 \pm 0.52$ & $16.7 \pm 0.45$ & $* * 15.0 \pm 0.37$ & $* * * 13.9 \pm 0.49$ \\
\hline
\end{tabular}

Note: $* * * \mathrm{P}<0,001 ; * * \mathrm{P}<0,01 ; * \mathrm{P}<0,05$.

Cows' life span of group II was higher than for peers of group I by 503 days $(31,2 \%$; $\mathrm{P}<0,001)$, group III by 105 days $(5,2 \% ; \mathrm{P}<0,05)$, group IV - by 694 days $(48,8 \%$; $\mathrm{P}<0,001)$. By productive use duration cows of the group II exceeded peers of group I by 435 days $(61,3 \% ; \mathrm{P}<0,001)$, group III - by 86 days $(8,1 \% ; \mathrm{P}<0,01)$, group IV - by 592 days $(107,1 \% ; \mathrm{P}<0,001)$.

The obtained results showed that the highest lifetime milk yields were for cows of group II $-19120 \mathrm{~kg}$ of milk. This is more compared to group I by $9711 \mathrm{~kg}$ of milk $(103,2 \% ; \mathrm{P}<0,001)$, group III - by $3277 \mathrm{~kg}(20,7 \%$; $\mathrm{P}<0,05)$, group IV - by $11445 \mathrm{~kg}$ $(149,1 \% ; \mathrm{P}<0,001)$.

Per 1 day of life from cows of group II milked more than from group I by $3,2 \mathrm{~kg}$ $(55,2 \% ; \mathrm{P}<0,001)$, group III - by $1,1 \mathrm{~kg}(13,9 \%$; $\mathrm{P}<0,05)$, group IV - by $3,6 \mathrm{~kg}(66,7 \%$; $\mathrm{P}<0,001)$. The difference in milk yield per 1 day of lactation was, respectively, $3,4 \mathrm{~kg}$ $(25,6 \% ; \mathrm{P}<0,001), 1,7 \mathrm{~kg}(1,3 \% ; \mathrm{P}<0,01), 2,8 \mathrm{~kg}(20,1 \% ; \mathrm{P}<0,001)$.

\section{Discussion}

High level of culling of dairy cows due to limb disease causes enormous economic damage to the entire dairy industry. In this regard, scientists and practitioners are making attempts to solve this problem by studying the factors that cause the onset of diseases, and methods that maximize its negative impact on the animal organism. It is known that the shape and dimensions of hooved horn shoe protect its soft parts from the mechanical and chemical effects of environmental elements, and also ensure uniform distribution of the animal's organism weight across all four limbs.

It was found that the formation of the horn shoe shape is of fundamental importance in limbs setting, the location of the putty bone (fetlock), and the hoof bone shape. Under its influence, the front wall inclination angle of hoof horn, which determines the shape of the hooves, is laid and formed. The most important, in this regard, are the first months of the calf's life, when the formation of the hoof and hooves takes place.

Research results showed that $48.8 \%$ of retired cows had hooves with anterior wall angle $51-55^{\circ}$. At the same time, the cows of this group were distinguished by the longest periods of life and productive use, as well as the highest milk yield on average for lactation and in general for the entire period of productive use. It should be noted that the highest milk yield for lactation and the longest period of life were in cows with front wall inclination angle of hoof horn of $50^{\circ}$. All deviations in the direction of increasing or decreasing the indicator led to a reduction in life period due to various injuries and diseases of the limbs and hooves, and, as a result, to a decrease in the level of milk productivity. The lowest indicators of productive longevity were found in the group of cows with front wall inclination angle of hoof horn less than $45^{\circ}$.

When keeping cows on hard concrete or slatted floors, the decisive condition for maintaining the health of limbs and hooves is the correct form and biophysical qualities of the horn shoe walls. It was established that the signs - hardness and elasticity, are in a certain interaction with each other and affect the incidence of limbs and the productive 
longevity of cows. The obtained results confirm the data of various scientists who conducted the study of these signs on various materials. Studies have shown that current qualities are related by an inverse correlation dependence, i.e. with increasing hardness, the elasticity of the object decreases and vice versa.

The study of hoofed horn hardness and elasticity of cattle stock allows to conclude that for the manifestation of maximum wear resistance and protective properties, the hoofed horn should possess these two qualities in an optimal ratio. It is very important, since the increased hardness of the keratin substance leads to delamination, cracking, creases of the walls of the hoof shoe, and, as a rule, its elasticity decreases. Excessive elasticity is accompanied by a decrease in hardness, which leads to a quick erasure of the edges of the walls of the horn shoe of the hooves and, ultimately, damage and infection of the sole crumbs.

Analysis of the has established that the best indicators of productive longevity were in cows with hoof horn hardness of 86-90 ShA and elasticity of 2,6-3,0 $\times 10^{10}$. The percentage of cows with these indicators in the total number of former animals is in the first case $23,6 \%$, in the second case $24,8 \%$. The largest group of cows that left the herd due to limb disease is characterized by a decrease in hardness and an increase in elasticity index of the hoof horn. In animals of this group, there was a decrease in the period of life and the level of milk production, both on average for lactation and for the entire period of use. This suggests that in most cows in the herd, the hoof horn quality is lower than the biological norm and it is very important to identify the deficiencies that caused disturbances in the growth and development of animals.

\section{Conclusion}

The research results showed that the shape of the horn shoe and the biophysical qualities of the hoofed horn in cattle stock have fundamental influence on the productive longevity and the cows' milk production level. In this regard, it is recommended to use the results of assessing the shape and quality of animal hooves when selecting livestock. For further use, preference is given to cows having front wall inclination angle of the hoof shoe $50-55^{\circ}$, hardness hoofed horn 86-90 ShA, elasticity $-2,6-3,0 \times 10^{10} \mathrm{~Pa}$.

\section{References}

1. J. Beck, PLoS ONE 5(5), 10-16 (2018)

2. C. Hammami, B. Rekik, E. Bastin et al., J of dairy Sciences 92(9), 4604-4612 (2019)

3. C. Hammami, B. Rekik, H. Soyeurt et al., J. Anim. Breed. Zhenya 126(5), 366-377 (2017)

4. D.G. Lemay, D. J. Lynn, F.Z. Martin, Genomic biology 10(4), $43-48$ (2015)

5. I. Flori, S. Fritz, F. Jaffrezic, M. Boussaha, PLoS ONE 4(8), 65-95 (2019)

6. M.J. Haskell, J. Dairy Sci. 89, 4259-4266 (2006)

7. A.E. Barberg, J. Dairy Sci. 90, 1575-1583 (2010)

8. G.B. Penner, J. Dairy Sci. 90, 365-375 (2010)

9. C. Hammami, B. Rekik, H. Soyeurt et al., J. dairy Science 91(9), 3661-3671 (2018)

10. J. Lewis, Z. Abas, S. Dadousis et al., PLoS ONE 6(4), 18-27 (2015)

11. E. Seroussi, G. Glick, A. Shirak, E. Yakodson et al., BMC Genomics 11, 673-701 (2015)

12. J. Weller, M. Ron, J. dairy Science 94(3), 1082-1090 (2016) 
13. G. Cramer, Proceedings of the International Lameness in Ruminants Symposium, 160164 (Kuopio, Finland, 2008)

14. Ch. Guard, Proceedings of the 15th International Lameness in Ruminants Symposium (Kuopio, Finland, 2008)

15. M. Holzhauer, J. Vos, Proceedings of the 15nd International Lameness in Ruminants Symposium, Poster Abstracts (Kuopio, Finland, 2008) 